\title{
Dahlia Inulin and Lactobacillus sp. in Step Down Protein Diet on Villi Development and Growth of KUB Chickens
}

\author{
S.A. Purbarani*, H.I. Wahyuni, \& N. Suthama \\ Faculty of Animal and Agricultural Sciences, Diponegoro University, \\ Tembalang Semarang 50275, Central Java, Indonesia \\ ${ }^{*}$ Corresponding author: saraswatipurbarani85@gmail.com \\ (Received 02-08-2018; Revised 01-10-2018; Accepted 02-11-2018)
}

\begin{abstract}
The research was aimed to evaluate the inclusion effect of dahlia tubers inulin (DTI) combined with Lactobacillus sp. in dietary protein step down on villi-development and growth of KUB chicken. The experiment was arranged in a completely randomized design using 160 birds of one-day-old KUB chicks (body weight was $26.32 \pm 1.19 \mathrm{~g}$ ) divided into 5 treatments with 4 replications. The treatment applied were: (1) P180S: ration with $18 \%$ protein with the addition of $1.2 \%$ DTI and $1.2 \mathrm{~mL}\left(10^{8}\right.$ $\mathrm{cfu} / \mathrm{mL}$ ) Lactobacillus sp. provided since one-day-old, (2) P15: ration with 15\% protein without DTI and Lactobacillus addition and was given from 8-day old, (3) P18: ration with 18\% protein without DTI and Lactobacillus addition and was given from 8-day old, (4) P15S: ration with 15\% protein with the addition of $1.2 \%$ DTI and $1.2 \mathrm{~mL}$ Lactobacillus sp. offered from 8-day old, and (5) P18S: ration with $18 \%$ protein with the addition of $\mathbf{1 . 2} \%$ DTI and $\mathbf{1 . 2} \mathrm{mL}$ Lactobacillus sp. offered from 8-day old. The experimental birds allocated in the treatments 2 to 5 were fed ration with $21 \%$ protein from hatching until 7 -day old. Variables observed were the jejunal $\mathrm{pH}$, total Coliform and lactic acid bacteria (LAB), villi height, protein digestibility, final body weight, and carcass percentage. Data were subjected to analysis of variance (ANOVA), and followed by orthogonal contrast test. Orthogonal contrast test showed that feeding $18 \%$ dietary protein fortified with a combination of $1.2 \%$ inulin dahlia tuber and $1.2 \mathrm{~mL}$ Lactobacillus $s p$. given since one-day-old significantly $(\mathrm{P}<0.05)$ affected the height of jejunal villi, protein digestibility, carcass percentage, final body weight, jejunal $\mathrm{pH}$, and Coliform number. In conclusion, feeding $18 \%$ dietary protein fortified with a combination of $\mathbf{1 . 2} \%$ of inulin dahlia tuber and $\mathbf{1 . 2} \mathrm{mL}$ of Lactobacillus $s p$. since one-day-old increases the height of the jejunum villi and growth of KUB chicken.
\end{abstract}

Keywords: dahlia tuber inulin; Lactobacillus sp.; step down protein; villi height; KUB chicken

\section{INTRODUCTION}

Selected native chicken (KUB) is a population of descendants obtained after 6 generations of systematicallycontrolled breeding system among pure local chickens as the ancestors originating from several areas in West Java. As a result of selection, KUB chickens have some advantages compared to either their ancestors or other local chickens in general. The advantages were indicated by the higher egg production, namely 160-180 eggs per year, high hatchability, better feed conversion ratio (FCR), and body weight of 700 to $1000 \mathrm{~g}$ that can be achieved within 10 weeks (Sartika, 2016). KUB chicken can be categorized as a meat producer. Meat production of KUB chicken is expected to have an important contribution to the fulfillment of national meat needs due to the increasing demand for chicken meat. It was reported that the production of local-chicken meat in Indonesia in 2015 was about 299.773 tons and increased to 315,538 tons in 2016 (Badan Pusat Statistik, 2016).

High-quality ration with balance nutrients content for growing poultry is needed to increase productiv- ity because the performance of chicken is absolutely depending on the ration quality and the adequacy of nutrients supply. The ration of KUB chicken at the first until the third week of age was recommended to contain $21 \%$ protein and at the further weeks the protein concentration of the ration was better to be decreased to $17 \%$ dietary protein in order to reach 700 to 1000 $\mathrm{g}$ of body weight within 10 weeks (Sartika, 2016). To achieve a faster growth stimulation, chickens should be provided sufficient protein diet at the beginning of the growing stage in order to achieve a high meat production. However, native chickens (kedu) provided with low dietary protein $(13 \%)$ fortified with a combination of $1.2 \%$ inulin dahlia tuber and $1.2 \mathrm{~mL}$ Lactobacillus $\mathrm{sp}$. $\left(10^{8} \mathrm{cfu} / \mathrm{mL}\right)$ resulted meat protein mass and cumulative body weight gain higher than feeding ration with $17 \%$ protein without supplementation (Wahyuni et al., 2017). It can be compared to study of Fajrih et al. (2014) that the improved body weight gain could be correlated with the better health status as was indicated by the increased weight of bursa fabricius in crossbred local chickens fed diet added with prebiotic inulin of dahlia tuber 
at the level of $1.2 \%$. The other phenomenon have been reported in crossbred local chickens given reduced protein diet $(18 \%)$ with the inclusion of $1.2 \mathrm{~mL}$ Lactobacillus $s p$. increased meat protein mass (Abdurrahman et al., 2016a), and on the contrary, decreased meat fat mass and cholesterol (Abdurrahman et al., 2016b). Similarly, Faradila et al. (2016) reported that feeding combinations of $1.2 \%$ inulin dahlia tuber and Lactobacillus sp. at $1.2 \mathrm{~mL}$ $\left(10^{8} \mathrm{cfu} / \mathrm{mL}\right)$ in crossbred native chicken resulted in the highest lactic acid bacteria population and body weight, but lower small intestinal $\mathrm{pH}$ and total Coliform. These results were consistent with the results of Beski et al. (2015) that broiler chicken fed with probiotic or synbiotic had higher villi than the control group. Based on the previous results, it can be assumed that the combination of probiotic (Lactobacillus sp.) and prebiotic (inulin dahlia) modulates the balance of intestinal microbes and improves the gastrointestinal health status that have a positive impact on nutrient digestibility.

Therefore, research concerning the combination of prebiotics inulin dahlia tuber and probiotics Lactobacillus sp. was conducted in KUB chickens considering that this topic has never been conducted previously. The inclusion of a combination of inulin dahlia tuber and Lactobacillus sp. in the rations with protein content was lowered (21-18\% vs. $21-15 \%$ ) and offered with different feeding periods (1-70 vs. 8-70 days) was conducted in the present study. Feeding such combination is expected to increase the productive efficiency by reducing the protein content of the ration but still be able to maintain the health of the digestive tract based on the $\mathrm{pH}$ of jejunum and Coliform, total lactic acid bacteria (LAB) and villi height, and even it was expected to increase protein digestibility and productivity (final body weight and carcass percentage).

\section{MATERIALS AND METHODS}

\section{Experimental Animal, Feed, and Equipment}

Inulin derived from dahlia tuber powder was selfpreparation at the laboratory and probiotic Lactobacillus sp. culture obtained from Center for Food and Nutrition Studies, Universitas Gadjah Mada were used in the present study. The experimental animals were 160 birds of one-day-old selected local chickens (KUB) with an initial body weight of $26.32 \pm 1.19 \mathrm{~g}$. During the first week, the experimental birds were kept in the individual cage (battery) coated with a net to avoid the chickens jumping out since they were still small enough. The experimental KUB chicks were given a small portion of feed mixed with inulin dahlia tuber and Lactobacillus sp. according to the treatments. The mixed feed was offered in the morning to ensure that inulin dahlia tuber and Lactobacillus sp. can be completely consumed, and the remaining feed was added thereafter to fulfill daily consumption. The experimental feed was provided from the age of 8 days until 70 days old, except for the treatment of P180S which would be clearly described in the next sub-heading. Drinking water was given ad libitum and the vaccine of Newcastle Disease (ND) was offered at the ages of 3 and 21 days old, while gumboro vaccine was administered on the ages of 7 and 28 days old. There were 3 basal experimental feeds with reduced protein or protein step down, namely, 21\%, 18\%, and 15\% (Table 1).

\section{Experimental Design, Variable, and Statistical Analysis}

The experiment was arranged in a completely randomized design using 5 treatments and 4 replications with 8 birds in each replication. The first treatment was P180S: ration with $18 \%$ protein with the addition of $1.2 \%$ dahlia tuber inulin (DTI) and $1.2 \mathrm{~mL}\left(10^{8} \mathrm{cfu} / \mathrm{mL}\right)$ Lactobacillus sp. provided since one-day-old. The second treatment was P15: ration with $15 \%$ protein without DTI and Lactobacillus sp. addition and was given from 8-day old. The third treatment was P18: ration with $18 \%$ protein without DTI and Lactobacillus sp. addition and was given from 8-day old. The fourth treatment was P15S: ration with $15 \%$ protein with the addition of $1.2 \%$ DTI and $1.2 \mathrm{~mL}$ Lactobacillus sp. offered from 8-day old. The fifth treatment was P18S: ration with $18 \%$ protein with the addition of $1.2 \%$ DTI and $1.2 \mathrm{~mL}$ Lactobacillus sp. offered from 8-day old. The birds that were allocated for treatments 2 to 5 were fed ration with $21 \%$ protein until 7-day old, and they were given the dietary treatment thereafter starting on day 8. The overall feeding scheme and duration are presented in Table 2.

The samples of jejunum were collected on day 35, and the height of villi was determined by cutting the jejunum approximately $2 \mathrm{~cm}$ length after the digesta was removed. The sample of jejunal villi was soaked in $10 \%$ buffer of neutral formaldehyde (BNF) for 24 hours, and then dehydrated using a stratified alcohol solution, and infiltrated with stratified xylol solution prior to be

Table 1. Composition and nutrient contents of experimental feed

\begin{tabular}{lrrr}
\hline & \multicolumn{3}{c}{ Dietary protein } \\
\cline { 2 - 4 } & $21 \%$ & $18 \%$ & $15 \%$ \\
\hline Ingredients (\%) & 20.80 & 26.40 & 27.00 \\
$\quad$ Rice bran & 40.20 & 44.20 & 50.70 \\
Yellow corn & 27.20 & 20.90 & 15.50 \\
Soybean meal & 10.00 & 6.50 & 4.50 \\
Fish meal & 1.00 & 1.20 & 1.40 \\
CaCO $_{3}$ & 0.80 & 0.80 & 0.90 \\
Premix & 100.00 & 100.00 & 100.00 \\
Total & & & \\
Nutrient contents (\%) & & & \\
Metabolizable energy ${ }^{2)}$ & $2,898.49$ & $2,867.07$ & $2,868.61$ \\
(kcal/kg) $_{\text {Crude protein }{ }^{1)}}$ & 21.33 & 17.68 & 14.87 \\
Ca $^{1)}$ & 1.17 & 1.02 & 0.97 \\
P $^{1)}$ & 0.66 & 0.59 & 0.55 \\
Lysine $^{3)}(\%)$ & 1.38 & 1.08 & 0.85 \\
Methionine $^{3)}(\%)$ & 0.45 & 0.37 & 0.32 \\
\hline
\end{tabular}

Note:

1) Analyzed value at the Laboratory of Nutrition and Feed Science, Faculty of Animal and Agricultural Sciences, Diponegoro University

2) Calculated value based on Balton (1967)

3) Calculated value based on Table of National Research Council (1996) 
Table 2. Duration and detail of feeding step-down dietary protein with the inclusion of dahlia tuber inulin (DTI) and Lactobacillus sp. in KUB chicken

\begin{tabular}{lccccccccc}
\hline \multirow{2}{*}{ Feeding detail } & \multicolumn{1}{c}{ Treatments } \\
\cline { 2 - 9 } & P180S & \multicolumn{1}{c}{ P15 } & \multicolumn{3}{c}{ P18 } & \multicolumn{2}{c}{ P15S } & \multicolumn{1}{c}{ P18S } \\
\hline Feeding duration (day) & $1-70$ & $1-7$ & $8-70$ & $1-7$ & $8-70$ & $1-7$ & $8-70$ & $1-7$ & $8-70$ \\
Dietary protein (\%) & 18 & 21 & 15 & 21 & 18 & 21 & 15 & 21 & 18 \\
Additive DTI and Lactobacillus sp. & & + & - & - & - & - & + & + & - \\
Feeding duration of additive (day) & $1-70$ & - & - & - & - & - & $8-70$ & - & $8-70$ \\
\hline
\end{tabular}

Note: P180S: ration with $18 \%$ protein with the addition of $1.2 \%$ DTI and $1.2 \mathrm{~mL}(108 \mathrm{cfu} / \mathrm{mL})$ Lactobacillus sp. provided since the age of one day (1-70). P15: ration with $15 \%$ protein without DTI and Lactobacillus sp. addition and was given since the age of 8 days (8-70).

P18: ration with $18 \%$ protein without DTI and Lactobacillus sp. addition and was given since the age of 8 days (8-70).

P15S: ration with 15\% protein with the addition of 1.2\% DTI and $1.2 \mathrm{~mL}$ Lactobacillus sp. and was given since the age of 8 days (8-70).

P18S: ration with $18 \%$ protein with the addition of $1.2 \%$ DTI and $1.2 \mathrm{~mL}$ Lactobacillus sp. and was given since the age of 8 days (8-70).

The birds allocated in the treatments of P15 to P18S were fed ration with 21\% protein until the age of 7 days (1-7).

planted using paraffin. The jejunal tissue was slashed by $6 \mu \mathrm{m}$ in size using microtome and pasted in the glass object with the aid of albumin adhesive, and hematoxylin-eosin staining method was performed thereafter (Harimurti \& Rahayu, 2009).

Lactic acid bacteria (LAB), Coliform, $\mathrm{pH}$ of digesta, protein digestibility, final body weight, and carcass percentage were measured on day $70^{\text {th }}$. Carcass percentage was obtained by dividing carcass weight with live weight and multiplied by $100 \%$. Protein digestibility was measured by combining two methods of total collection and indicator (Indreswari et al., 2009) with the formula of McDonald et al. (2002) as follows:

Protein digestibility $=[$ (protein consumed - protein in excreta)/protein consumed] $\times 100 \%$

The birds were decapitated and then dissected to obtain the digesta from the jejunum for total LAB and Coliform counts, and $\mathrm{pH}$ measurement. The digesta was divided into 2 portions, one portion for $\mathrm{pH}$ measurement using $\mathrm{pH}$ meter, and another portion was kept in sterile and tightly sealed bottle for LAB and Coliform counts determination. Measurement of total LAB and Coliform were performed using total plate count (TPC) according to the method of Fardiaz (1992) as follows:

Total colony $(\mathrm{cfu} / \mathrm{g})=$ total colony $\mathrm{x}(1 /$ dilution factor $) \mathrm{x}$ (1/sample weight)
Data were statistically analyzed to evaluate treatment effect using analysis of variance and continued to differentiation test with orthogonal contrast.

\section{RESULTS}

\section{Microbial Profile and Jejunal pH}

Fortified diets with a combination of dahlia tuber inulin (DTI) and Lactobacillus sp. fed with different durations and dietary proteins (step down protein) significantly $(\mathrm{P}<0.05)$ affected jejunal $\mathrm{pH}$, lactic acid bacteria (LAB) population, and total Coliform (Table 3). The jejunal $\mathrm{pH}$ ranged from 5.8 to 6.9 , LAB population ranged from $2.6 \times 10^{8}$ to $6.8 \times 10^{8} \mathrm{cfu} / \mathrm{g}$, whereas Coliform count ranged from $3.1 \times 10^{6}$ to $9.3 \times 10^{6} \mathrm{cfu} / \mathrm{g}$.

\section{The Height of Jejunal Villi and Protein Digestibility}

A significant effect $(\mathrm{P}<0.05)$ was also found on the height of villi and protein digestibility (Table 4) due to feeding dietary inclusion of a combination of dahlia tuber inulin (DTI) and Lactobacillus sp. that offered with different durations and dietary proteins (step down protein). The villi height ranged from 716.4 to $1090.2 \mu \mathrm{m}$, whereas the protein digestibility ranged from $37.74 \%$ to $70.75 \%$.

Table 3. Jejunal pH, Coliform counts, and total lactic acid bacteria (LAB) in KUB chicken fed step-down dietary protein with the inclusion of dahlia tuber inulin (DTI) and Lactobacillus sp.

\begin{tabular}{|c|c|c|c|}
\hline \multirow{2}{*}{ Treatments } & \multicolumn{3}{|c|}{ Variables } \\
\hline & $\mathrm{pH}$ & Coliform (cfu/g) & LAB (cfu/g) \\
\hline P180S & $5.80 \pm 0.22$ & $3.1 \times 10^{6} \pm 6.0 \times 10^{5}$ & $6.8 \times 10^{8} \pm 6.9 \times 10^{7}$ \\
\hline P15 & $6.90 \pm 0.09$ & $9.3 \times 10^{6} \pm 6.4 \times 10^{5}$ & $2.6 \times 10^{8} \pm 3.6 \times 10^{7}$ \\
\hline P18 & $6.40 \pm 0.40$ & $5.4 \times 10^{6} \pm 5.9 \times 10^{5}$ & $3.1 \times 10^{8} \pm 2.1 \times 10^{7}$ \\
\hline P15S & $6.60 \pm 0.12$ & $8.0 \times 10^{6} \pm 4.5 \times 10^{5}$ & $3.0 \times 10^{8} \pm 3.7 \times 10^{7}$ \\
\hline P18S & $6.12 \pm 0.09$ & $5.0 \times 10^{6} \pm 8.3 \times 10^{5}$ & $4.2 \times 10^{8} \pm 2.5 \times 10^{7}$ \\
\hline Comparison of treatments & \multicolumn{3}{|c|}{ Comparison of values } \\
\hline P180S vs P15 & 5.80 vs $6.90^{*}$ & $3.1 \times 10^{6}$ vs $9.3 \times 10^{6 *}$ & $6.8 \times 10^{8}$ vs $2.6 \times 10^{8 *}$ \\
\hline P180S vs P18 & 5.80 vs $6.40^{*}$ & $3.1 \times 10^{6}$ vs $5.4 \times 10^{6 *}$ & $6.8 \times 10^{8}$ vs $3.1 \times 10^{8 *}$ \\
\hline P180S vs P15S & 5.80 vs $6.60^{*}$ & $3.1 \times 10^{6}$ vs $8.0 \times 10^{6 *}$ & $6.8 \times 10^{8}$ vs $3.0 \times 10^{8 *}$ \\
\hline P180S vs P18S & 5.80 vs $6.12^{*}$ & $3.1 \times 10^{6}$ vs $5.0 \times 10^{6 *}$ & $6.8 \times 10^{8}$ vs $4.2 \times 10^{8 *}$ \\
\hline
\end{tabular}

Note: *Significantly different $(\mathrm{P}<0.05)$ with orthogonal contrast test. 


\section{Final Body Weight and Carcass Percentage}

A similar phenomenon was observed for final body weight and carcass percentage (Table 5) which were significantly $(\mathrm{P}<0.05)$ affected by the dietary inclusion of a combination of dahlia tuber inulin (DTI) and Lactobacillus sp. that provided with different durations and dietary proteins (step down protein). The final body weight ranged from 427.8 to $737.8 \mathrm{~g}$, whereas the carcass percentage ranged from $48.80 \%$ to $70.99 \%$.

\section{DISCUSSION}

\section{Microbial Profile and Jejunal pH}

Ration with $18 \%$ protein fortified with a combination of $1.2 \%$ DTI and $1.2 \mathrm{~mL}$ Lactobacillus sp. given since one-day-old resulted in the lowest jejunal $\mathrm{pH}$ (5.8) and total Coliform $\left(3.1 \times 10^{6} \mathrm{cfu} / \mathrm{g}\right)$ with the highest lactic acid bacteria $(\mathrm{LAB})$ population $\left(6.8 \times 10^{8} \mathrm{cfu} / \mathrm{g}\right)$ compared to the other treatments (P15, P18, P15S, and P18S) (Table $3)$. Based on the comparison of orthogonal contrast test, the inclusion of DTI and Lactobacillus sp. to $18 \%$ dietary protein was much more effective when it was given since one-day-old.

The increased jejunal acidity and total Coliform brought about the reduced development of LAB with step down dietary protein without DTI and Lactobacillus sp. supplementation when given from 8-day old (P15, P18). Dietary treatments without the additions of DTI and Lactobacillus sp. caused the failure of increasing LAB population and of lowering pathogenic bacteria (Coliform). Feeding DTI as a prebiotic was reported to be beneficial for the development of small intestinal microbes (Krismiyanto et al., 2014). Roberfroid (2007) stated that inulin could be fermented by the intestinal microbes, such as Lactobacillus sp., and the products of fermentation caused the decrease in $\mathrm{pH}$ of the digestive tract which stimulated the increase in the amount of non-pathogenic bacteria. Similarly, Hui-Ling et al. (2011)

Table 4. The height of jejunal villi and protein digestibility in KUB chicken fed step-down dietary protein with the inclusion of dahlia tuber inulin (DTI) and Lactobacillus sp.

\begin{tabular}{ccc}
\hline \multirow{2}{*}{ Treatments } & \multicolumn{2}{c}{ Variables } \\
\cline { 2 - 3 } & $\begin{array}{c}\text { The height of villi } \\
(\mu \mathrm{m})\end{array}$ & $\begin{array}{c}\text { Protein } \\
\text { digestibility }(\%)\end{array}$ \\
\hline P180S & $1090.20 \pm 73.72$ & $70.75 \pm 5.98$ \\
P15 & $716.40 \pm 12.06$ & $37.74 \pm 5.92$ \\
P18 & $973.70 \pm 67.42$ & $57.51 \pm 1.55$ \\
P15S & $853.12 \pm 63.23$ & $48.60 \pm 5.69$ \\
P18S & $989.10 \pm 69.15$ & $61.70 \pm 4.80$ \\
\hline Comparison of & \multicolumn{2}{c}{ Comparison of values } \\
treatments & \multicolumn{2}{c}{1090.20 vs $716.40^{*}$} \\
\hline P180S vs P15 & 70.75 vs $37.74^{*}$ \\
P180S vs P18 & 1090.20 vs $973.70^{*}$ & 70.75 vs $57.51^{*}$ \\
P180S vs P15S & 1090.20 vs $853.12^{*}$ & 70.75 vs $48.60^{*}$ \\
P180S vs P18S & 1090.20 vs $989.10^{*}$ & 70.75 vs $61.70^{*}$ \\
\hline
\end{tabular}

Note: *Significantly different $(\mathrm{P}<0.05)$ with orthogonal contrast test. and Ravangard et al. (2017) reported that dietary inclusion of probiotic and prebiotic combination fed from day 1 to 42 in broiler increased the populations of intestinal Lactobacillus and Bifidobacterium but suppressed the E. coli counts. Other study results (Erdogan et al., 2010) indicated that the dietary addition of $1 \mathrm{~g}$ synbiotic and phytobiotics per $\mathrm{kg}$ feed given in broiler from 1 to 42 days old impaired the development of Coliform as compared to control group.

Step down protein diet with the inclusion of DTI and Lactobacillus sp. given from the age of 8 days (P15S and P18S) was able to increase the LAB population, but decreased the Coliform number and jejunal $\mathrm{pH}$. However, when the combination was given since one-day-old without a step down protein (P180S), the treatment lowered jejunal $\mathrm{pH}$, Coliform number, and increased total LAB. These results were supported by the previous study (Carvalho \& Hansen, 2005) that feeding synbiotic from the early stage of age was effective to stimulate the growth of bacteria in the digestive tract to be more balance to ensure the health of the host. An appropriate age of feeding of synbiotic in broiler chickens was recommended at 2 days old in order to improve the health of the small intestine and increased the height of villi, which in turn could increase nutrient digestibility, especially protein (Hamid et al., 2014).

\section{The Height of Jejunal Villi and Protein Digestibility}

The highest values of height of villi $(1090 ; 2 \mu \mathrm{m})$ and protein digestibility $(70.75 \%)$ compared to the other treatments (P15, P18, P15S, and P18S) were the results due to the feeding effect of $18 \%$ dietary protein fortified with a combination of 1.2\% DTI and $1.2 \mathrm{~mL}$ Lactobacillus sp. given since one-day-old (Table 4). It was clearly indicated by the orthogonal contrast test that the effect of $18 \%$ dietary protein with the inclusion of dahlia tuber inulin and Lactobacillus sp. without a step down protein was the best when it was fed earlier since one-day-old.

The height of jejunal villi in P180S treatment increased as compared to those in P15, P18, P15S, and

Table 5. Final body weight and carcass percentage of KUB chicken fed step-down dietary protein with the inclusion of dahlia tuber inulin (DTI) and Lactobacillus sp.

\begin{tabular}{|c|c|c|}
\hline \multirow[b]{2}{*}{ Treatments } & \multicolumn{2}{|c|}{ Variables } \\
\hline & $\begin{array}{l}\text { Final body weight } \\
\text { (g/bird) }\end{array}$ & $\begin{array}{c}\text { Carcass weight } \\
(\%)\end{array}$ \\
\hline P180S & $737.80 \pm 43.83$ & $70.99 \pm 2.32$ \\
\hline P15 & $427.80 \pm 43.97$ & $48.80 \pm 2.87$ \\
\hline P18 & $606.80 \pm 32.97$ & $60.50 \pm 3.00$ \\
\hline P15S & $540.50 \pm 43.62$ & $58.89 \pm 1.71$ \\
\hline P18S & $646.50 \pm 37.72$ & $64.06 \pm 0.82$ \\
\hline $\begin{array}{l}\text { Comparison of } \\
\text { treatments }\end{array}$ & \multicolumn{2}{|c|}{ Comparison of values } \\
\hline P180S vs P15 & 737.80 vs $427.80^{*}$ & 70.99 vs $48.80^{*}$ \\
\hline P180S vs P18 & 737.80 vs $606.80^{*}$ & 70.99 vs $60.50^{*}$ \\
\hline P180S vs P15S & 737.80 vs $540.50^{*}$ & 70.99 vs $58.89^{*}$ \\
\hline P180S vs P18S & 737.80 vs $646.50^{*}$ & 70.99 vs $64.06^{*}$ \\
\hline
\end{tabular}

Note: *Significantly different $(\mathrm{P}<0.05)$ with orthogonal contrast test. 
P18S and this parameter increased along with the increased LAB population, and the decreased jejunal $\mathrm{pH}$ and Coliform number. The lower villi height in the birds fed step-down protein diet without addition of DTI and Lactobacillus sp. (P15 and P18) proved that the combination of those two additives was able to create a healthier digestive tract. In this case, inulin was assumed to function as "food" source that can trigger the production of short chain fatty acids (SCFA) as the final fermentation product. The production of SCFA brought about the intestinal atmosphere to be an acid condition that supported the development of lactic acid bacteria (LAB) and inhibited the growth of pathogenic bacteria (Nabizadeh, 2012). This condition was clearly related to the fortified effect of DTI and Lactobacillus sp. combination which indirectly stimulated the jejunal villi growth (Table 4). The present results were in accordance with the previous findings (Rehman et al., 2007; Nabizadeh, 2012) that dietary inclusion of inulin as a prebiotic stimulated the development of beneficial microbiotes of the gastrointestinal which played an important role in improving the growth of intestinal villi.

Combination of DTI and Lactobacillus sp. was also able to increase the heights of jejunal villi in P15S and P18S treatments, but the combination given from one day of age (P180S) can maximize the growth of jejunal villi when compared to those of both treatments above (P15S and P18S). This result proved clear evidence that the combination of DTI and Lactobacillus sp. increased villi height at a medium level although it was provided at the age of 8 days with step down dietary protein (Table 4). However, early administration of the additive combination resulted in the highest value of villi height. Feeding probiotics starting on early age could help the bird more quickly in establishing the balance of intestinal microflora (Kabir, 2009).

The balanced microflora condition further brought about a positive effect on the improvement of the health of intestinal lumen. The results of the present study were in line with the report of Hamid et al. (2014) that dietary administration of synbiotic since the age of 2 days improved the health of small intestine of the birds, and impact on the increase in the height of the villi. Similarly, Arifin et al. (2014), reported that early administration of a mixture of $3 \mathrm{~mL}$ of Bacillus subtilis $\left(8.2 \times 10^{8} \mathrm{cfu} / \mathrm{mL}\right)$ as probiotics and $2 \mathrm{~mL}$ L. Saccharomyces cerevisiae as prebiotic in broiler chickens stimulated the growth of villi. Also, Min et al. (2016) stated that the combination of probiotic Bacillus subtilis and prebiotic xylo-oligosaccharide and mannan-oligosaccharide given in broiler chickens since 1 day of age significantly increased the height of the villi and the dept of the crypt of the duodenum, jejunum, and ileum.

The height of jejunal villi in most cases can be associated with the higher protein digestibility. The inclusion of probiotics or synbiotics stimulated the growth of intestinal villi to be higher (Awad et al., 2009; Beski et al., 2015). The better growth of villi is beneficial for the health and function of the small intestine, which in turn increases nutrients digestibility, especially protein. It was shown that the addition of DTI combined with
Lactobacillus sp. given since one-day-old without a step down protein (P180S) resulted in a higher protein digestibility compared to the other treatments (P15, P18, P15S, and P18S) (Table 4). The increased protein digestibility found in P180S can be decisively argued to be caused by the "work and function of two eye scissors" namely, the stability of protein supply, since no dietary protein stepdown, and the role of DTI and Lactobacillus sp. combination.

\section{Final Body Weight and Carcass Percentage}

An $18 \%$ dietary protein with the inclusion of a combination of $1.2 \%$ DTI and $1.2 \mathrm{~mL}$ Lactobacillus sp. given since one-day-old resulted in the highest final body weight and carcass percentage (Table 5). These results were comparable to the other treatments of a step down protein with or without the addition of DIT and Lactobacillus sp. given from the age of 8-day old (P15, P18, P15S, P18S) which indicated the lower values. Orthogonal contrast test on these results suggested that the inclusion of a combination of dahlia tuber inulin and Lactobacillus sp. was much beneficial when added to $18 \%$ dietary protein and given since one-day-old.

In relation to the final body weight and the carcass percentage of the P180S treatment indicated the higher values compared to those of P15S and P18S (Table 5). The phenomenon can be connected with the more effective stimulation of the digestive tract development, which was characterized by the better composition and balance of intestinal bacteria, due to the early feeding dietary inclusion of prebiotic DTI and probiotic Lactobacillus sp. This condition positively provided an impact on the health of the digestive tract, thus leading to the increase of protein digestibility which finally improved productivity, in term of final body weight and carcass percentage. The present results were in accordance with the study of Suthama et al. (2018) that the increased LAB counts and protein digestibility in broiler fed dietary inclusion of soybean oligosaccharide at the level of $0.3 \%$ improved productivity, in case of carcass and meat quality. The present results reflected that LAB was able to compete with Coliform so that it had a positive implication on the increase in the height of villi and protein digestibility (Table 4), carcass, and body weight (Table 5). As it was discussed previously that the dietary addition of probiotics was assumed to produce SCFA, especially butyric acid, which could stimulate the development of intestinal epithelial cells. The better growth of intestinal cells, the higher number of nutrients can be absorbed due to the wider surface of the intestinal lumen (Ohashi \& Ushida, 2009). Further study (Cheng et al., 2017) indicated that the dietary inclusion of synbiotic given since the age of 1 day in broiler chickens increased body weight. It was observed in the present study that the absence of DTI and Lactobacillus sp., for example in P15 and P18 treatments, resulted in a slower villi development and lower protein digestibility (Table 4), and thus brought about a low productivity, in term of body weight and carcass percentage. 


\section{CONCLUSION}

Feeding $18 \%$ dietary protein fortified with $1.2 \%$ dahlia tuber inulin (DTI) and $1.2 \mathrm{~mL}$ Lactobacillus sp. given to the KUB chicken from one-day-old increases the height of jejunal villi, protein digestibility, carcass percentage, and final body weight with the lowest jejunal $\mathrm{pH}$ and Coliform number.

\section{CONFLICT OF INTEREST}

The authors would like to declare that there is no conflict of interest with any organization regarding either financial support or the experimental material, especially animals used as discussed in the manuscript. The experimental animals used in the present study and the approval were obtained from the PT. Ayam Kampung Indonesia, under license of Livestock Research Center Bogor, Indonesia.

\section{REFERENCES}

Abdurrahman, Z.H., Y. B. Pramono, \& N. Suthama. 2016a. Feeding effect of inulin derived from dahlia tuber combined with Lactobacillus sp. on meat protein mass of crossbred kampong chicken. J. Indonesian Trop. Anim. Agric. 41: 37-44. https://doi.org/10.14710/jitaa.41.1.37-44

Abdurrahman, Z.H., Y. B. Pramono, \& N. Suthama. 2016b. Meat characteristic of crossbred local chicken fed inulin of dahlia tuber and Lactobacillus sp. Med. Pet. 39: 112-118. https://doi.org/10.5398/medpet.2016.39.2.112

Arifin, M. \& V. J. Pramono. 2014. Pengaruh pemberian sinbiotik sebagai alternatif pengganti antibiotic growth promoter terhadap pertumbuhan dan ukuran villi usus ayam broiler. J. Sains Vet. 32: 205-217.

Awad, W.A., K. Ghareeb, S. Abdel-Raheem, \& J. Bohm. 2009. Effect of dietary inclusion of probiotic and synbiotic on growth performance, organ weights, and intestinal histomorphology of broiler chickens. Poult. Sci. 88: 49-55. https://doi.org/10.3382/ps.2008-00244

Balton, W. 1967. MAFF Bulletin. No. 174. Poultry Nutrition. HMSO, London.

Beski. S.S.M. \& S.Y.T. Al-Sardary. 2015. Effect of dietary suplementation of probiotic and synbiotic on broiler chickens Hematology and intestinal integrity. Poult. Sci. 14: 31-36. https://doi.org/10.3923/ijps.2015.31.36

Carvalho, N. \& S. Hansen. 2005. Prospect for probiotics in broiler. Feed Int. 26:9-12.

Cheng, Y., Y. Chen, X. Li, W. Yang, C. Wen, Y. Kang, A. Wang, \& Y. Zhou. 2017. Effect of synbiotic suplementation on growth performance, carcass characteristic, meat quality and muscular antioxidant capacity and mineral content in broilers. J. Sci. Food Agric. 97: 3699-3705. https://doi. org/10.1002/jsfa. 8230

Erdogan, Z., S. Erdogan, O. Aslantas, \& S. Celik. 2010. Effect of dietary supplementation of synbiotics and phytobiotics on performance, caecal Coliform population and some oxidant/antioxidant parameters of broliers. J. Anim. Physiol. Anim. Nutr. (Berl) 94: e40-8. https://doi. org/10.1111/j.1439-0396.2009.00973.x

Fajrih, N., N. Suthama, \& V. D. Yunianto. 2014. Body resistance and productive performances of crossbred local chicken fed inulin of dahlia tubers. Med. Pet. 37: 108-114. https:// doi.org/10.5398/medpet.2014.37.2.108
Faradila, S., N. Suthama, \& B. Sukamto. 2016. Kombinasi inulin umbi dahlia-Lactobacillus sp. yang mengoptimalkan perkembangan mikroflora usus dan pertumbuhan persilangan ayam Pelung-Leghorn. J. Vet. 17: 168-175.

Fardiaz, S. 1992. Analisis Mikrobiologi Pangan. Raja Grafindo Persada, Jakarta.

Hamid, I.S., B. P. S. Rahardjo, \& M. Gabriela. 2014. Potensi pemberian sinbiotik pada umur yang berbeda pada gambaran histologi ileum ayam pedaging betina. J. Vet. Medika 7: 114-119

Harimurti, S. \& E. S. Rahayu. 2009. Morfologi usus ayam broiler yang disuplementasi dengan probiotik strain tunggal dan campuran. Agritech 29: 179-183.

Huiling, Y., G. Yupeng, \& Z. Liyong. 2011. Effect of dietary synbiotics on intestinal microbial ecology in broilers chickens. Scientia Agricultura Sinica. 44: 4882-4891.

Indreswari, R., H.I. Wahyuni, N. Suthama, \& P.A. Ristiana. 2009. Calcium utilization for egg shell formation as affected by feeding ration in the morning and afternoon in layer chicken (In bahasa Indonesia). J. Indonesian Trop. Anim. Agric. 34: 134-138.

Kabir, S. M. L. 2009. The role of probiotics in the poultry industry. Int. J. Mol. Sci.10: 3531-3546. https://doi.org/10.3390/ ijms10083531

Krismiyanto, L., N. Suthama, \& H.I. Wahyuni. 2014. Feeding effect of inulin derived from dahlia variabilis tuber on intestinal microbes in starter period of crossbreed native chicken. J. Indonesian Tropis. Anim. Agric. 39: 217-223.

McDonald, P., R.A. Edward, J.F.G. Greenhalgh, \& C.A. Morgan. 2002. Animal Nutrition. $6^{\text {th }}$ ed. Gosport.

Min, Y.N., H.L. Yang, Y.X. Xu, \& Y.P. Gao. 2016. Effect of dietary supplementation of synbiotics on growth performance, intestinal morphology, SlgA content and antioxidant capacities of broliers. J. Anim. Physiol. Anim. Nutr. (Berl) 100: 1073-1080. https://doi.org/10.1111/jpn.12479

Nabizadeh, A. 2012. The effect of Inulin on broiler chicken intestinal microflora, gut morphologi and performance. J. Anim. Sci. 21: 725.

Ohashi, Y. \& K. Ushida. 2009. Health-beneficial effects of probiotics: Its mode of action. J. Anim. Sci. 80: 361-371. https:// doi.org/10.1111/j.1740-0929.2009.00645.x

Ravangard., M. Houshmand, M. Khajavi, \& R. Naghiha. 2017. Performance and cecal bacteria counts of broilers fed low protein diets with and without a combination of probiotic and prebiotic. Braz. J. Poult. Sci. 19: 75-82.

Rehman, H., C. Rosenkranz, J. Bohm, \& J. Zentek. 2007. Dietary inulin affects the morphology but not the sodiumdependent glucose and glutamine transport in the jejunum of broilers. Poult. Sci. 86: 118-122. https://doi.org/10.1093/ ps/86.1.118

Roberfroid, M.B. 2007. Inulin-type fructans: Functional food ingredients. J. Nutr. 137: 2493S-2502S. https://doi. org/10.1093/jn/137.11.2493S

Sartika, T. 2016. Panen Ayam Kampung 70 hari. Penebar Swadaya, Jakarta.

Suthama, N. Y.B. Pramono, \& B. Sukamto. 2018. Improvement of broiler meat quality due to dietary inclusion of soybean oligosaccharide derived from soybean meal extract. IOP Conf. Ser.: Earth Environ. Sci. 102 012009. https://doi. org/10.1088/1755-1315/102/1/012009

Wahyuni, H.I, N. Suthama, I. Mangisah, \& L. Krismiyanto. 2018. Improving protein mass and cumulative body weight gain of local chicken fed ration fortified with a combination of Lactobacillus sp. and dahlia inulin. IOP Conf. Ser.: Earth Environ. Sci. 102012072. 